\title{
Profitability and Company Value: Empirical Study of Manufacture Companies in Indonesia Period $2009-2014$
}

\author{
Siti Ayu Lestari, Mursalim Armayah \\ Faculty of Economics and Business, Hasanuddin University, Indonesia \\ mursalimnohong@fe.unhas.ac.id
}

\begin{abstract}
Maximizing the value of the company is one of the financial issues are interesting to study. Profitability is one of the factors that influence value of enterprise be in accordance with asset and equity owned. The purpose of this research is to describe the correlation between profitability and company value. Based on the problem and purpose research, the research is designed as quantitative research. Secondary data used as the basis for the analysis was obtained from ICMD with observation period of 5 years to 10 companies. Data analyzed by using linear regression multiple analyses. Empirical results show that profitability variability explains change of company value. Return on Investment and Return on Equity has positive and significant effect on company value, but Net Profit Margin negatively and significantly affects company value.
\end{abstract}

Keywords: Company value, profitability, and manufacture

\section{Introduction}

The main goal for a firm going public is to increase the shareholder welfare by increasing the value of a firm (Salvatore, 2005). The firm value is very important, as higher firm's value will increase the welfare of the stockholder (Brigham et al., 2006). The company's value is often associated with stock price growth, so the increase of stock price will also increase the value of the firm. The welfare of the shareholder and value of the firm are commonly represented on the stock price, which implicitly represent the investment decision, financing and asset management. Company value is one of the management's success in managing the company activities and decision making process. Besides that, firm value also reflects of market response to the company. Stakeholder theory explains that the increase in the value of the company which can be measured by the share price that showed shareholder wealth (Mursalim et al., 2015). Therefore, the increase in share prices will result in changes in the level of welfare. In a fiercely competitive environment, in order to both survive and develop, companies must work to achieve the cheapest way to carry out their investment plans and to maximize firm value and shareholder wealth.

In some financial literature, the market capitalization becomes a proxy for the value of the company. Market capitalization is calculated by multiplying the value of company stock market price by the number of shares outstanding. Therefore, the higher the company's share price and a larger number of shares outstanding in the market, the greater the company's market capitalization. Considering number of outstanding shares to be constant (except in the case of buyout or split share), the firm's value is largely affected by market price of firm (Rajhans and Kaur, 2013). Determining the value of a company has always been a challenge to economists and market practitioners, due to its importance and difficulty, because it requires a credible relation between accounting values and market value (Vergos et al., 2016). Baye (2006) defines firm value as the present value (PV) of current expected future cash flows. Shin-Ping and Hui-Ju (2011) state that shareholder's wealth, growth; dividend-payout, ratio and leverage are key determinants of firm value. Other research found company value is determined by assets, cash flow, relative worth and intangible assets such as corporate image/reputation and human resource (Huselid and Becker, 1997). However, in general, investors are more concerned with profitability as a basis for assessing a company. In addition, the ability company have benefited are also become factors of the best value of enterprise. Companies that obtain greater profit will be an option by investors. Theoretically, profit is a dividend variable that calculated by the firm each period. Therefore, through this study will be analyzed the effect of profitability on company value. 


\section{Literature Review}

Company Value: The conventional measure of firm value is obtained by adding the market value of equity to the market value of debt. However, this firm value measure includes all assets owned by the firm including its cash holdings. Netting cash out from firm value yields enterprise value, which can be considered to be the market value of just the operating assets of the firm. It means that, value also shows the performance achieved by the company from management activities are carried out effectively and efficiently. Stakeholders will respond positively demonstrated through the development of demand for the company's stock is issued to every success. Value is not only interested for stakeholders. It also determines the sustainability of the company in the future. Companies that are able to develop value in a sustainable manner will be a competitive company than others. Thus, the company's management is required to manage the activities and the ability to be able to create value. Meanwhile, Van Horne \& Wachowicz (2009) describes that value of the firm is determined by market price of the firm's common stock, which in turn is a reflection of the firm's investment, financial and dividend decisions.

Profitability: Profitability can be defined as the ability of a firm to generate profits. Sarngadharan \& Rajitha (2011) differentiate profit from profitability based on how it measure the earning capacity, in which profit is an absolute measure of earning capacity but profitability is a relative measure of earning capacity. Profit indicates a firm's earning during a specified period. While, profitability denotes whether these profits are constant or improved or deteriorated, how and to what extent they can be improved. That is why profits of two different firms might be identical, however not for the profitability. Company profitability was company's ability to generate net income from the activity undertaken in an accounting period. Profitability can become an important consideration for investors in their investment decisions. With a bid to get the high profits, was expected to attract investors in investing. Many leaders use financial performance as basis for company's performance. Companies that can get huge profits can be said to be successful, or have a good financial performance (Moeljadi, 2014). Profitability was the end result of a number policy and decision management (Brigham et al., 2006). Company profitability was a company's ability to generate net income from the activities carried out in an accounting period.

\section{Methodology}

This study is a causality research which designed to test correlation between profitability and company value. Research samples are manufacturing companies listed in Indonesia Stock Exchange 2009-2014. Criteria used to determine the sample are:

1. Manufacturing companies that regularly publish financial statements the period $2009-2014$

2. During the study period, the company makes a profit

Based on these criteria, then there are 10 companies sampled. The analytical techniques used to examine the relationship between variables are multiple regression analysis.

\section{Figure 1: Conceptual framework}

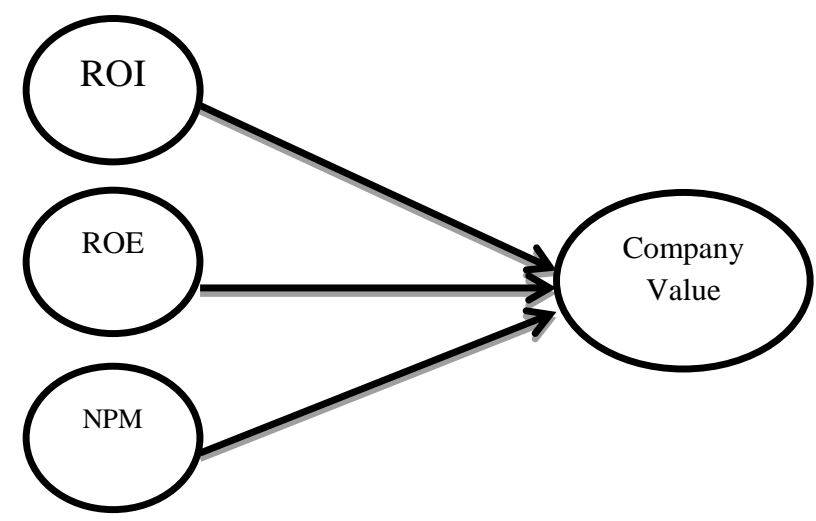

Based on the research problems, the purpose, and conceptual framework, then the hypothesis proposed are; 
- Return on Investment has positive and significant on company value

- Return on equity has positive and significant on company value

- Net profit margin has positive and significant on company value

\section{Results and Discussion}

Figure 2, 3, 4, and 5 showing the growth of dependent variable Return on Investment (ROI), Return on Equity (ROE), Net Profit Margin (NPM) and independent variable Price to Book Value (PBV) of period 2009- 2014. Based on figure data, it seems that the growth each variable vary of ROI, ROE, NPM and PBV. The firm ability have benefited from investment done varies amount 1,29-1,64 which the highest in 2011. This means companies in the sample able to manage asset owned so with optimally management can be obtained profit. Profitability which measured with ROE amount 1, $90-2,14$ which the highest in 2013. Profitability of firm can be achieved from NPM amount 1, 16 - 1, 26 which the highest in 2012 and 2013.
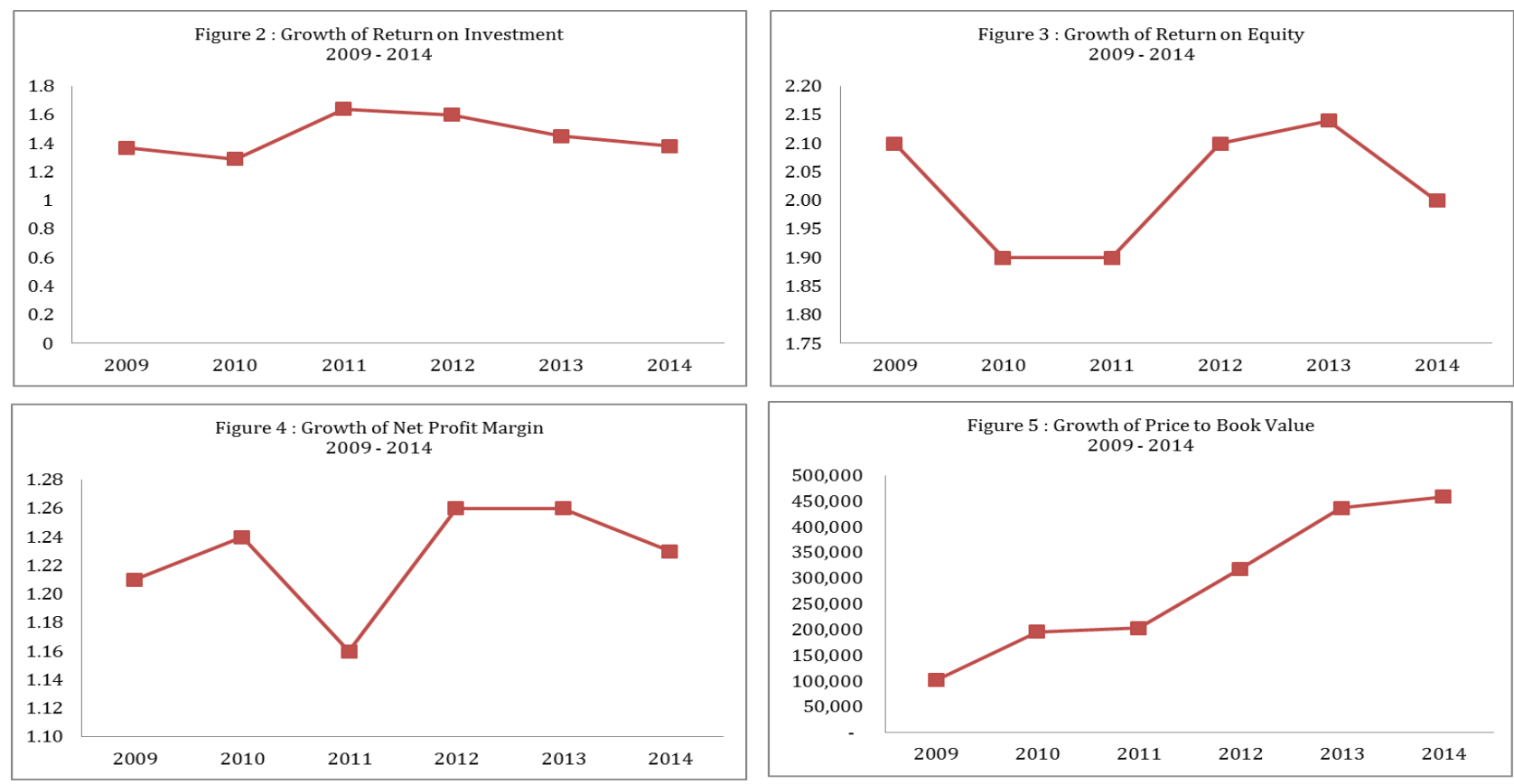

Source: Lestari \& Armayah (2016)

In contrast of independent variable growth which inclined to fluctuate? Dependent variable, PBV shows positive trend. The lowest PBV was in 2009 and the highest in 2014. It means that manufacture selected value in this research of period $2009-2014$ tend to increased. Based on calculation about the effect of profitability on company value the results as follow as:

Table 1: Summary of regression calculation

\begin{tabular}{lllll}
\hline Variables & Coefficient & Tolerance & VIF & Probability \\
\hline Constant & $-7.8153,306$ & - & - & 0,000 \\
ROI & 436922,782 & 0,335 & 2,982 & 0,022 \\
ROE & 439033,120 & 0,338 & 2,962 & 0,010 \\
NPM & -375045.468 & 0,645 & 1,549 & 0,004 \\
F Statistic & 14,827 & & & \\
Probability & 0,000 & & & \\
R & 0,443 & & \\
R Adjusted & 0,413 & & & \\
D-W & 1,329 & & & \\
\hline
\end{tabular}

Source: Lestari \& Armayah (2016) 
Discussion: Table 1 displays result of regression of the test for the effect of profitability toward Manufacture Company's value. Table 1 presents the empirical results of the regression of model using PBV as the company variable. The value for the $\mathrm{R}^{2}$ in the model is 0.44 which shows that $44 \%$ of the variation in the dependent variable is explained by the independent variables of the model. The $56 \%$ variation in the dependent variable remains unexplained by the independent variables of the study. The value for the F-statistic is 14.82 and is significant endorsing the validity and stability of the model relevant to the study. The results of variables suggest that there is a positive relationship between the ROI, ROE and PBV. This positive relationship shows that the ROI and ROE of a manufacture firms affects the value of the manufacture firms. The higher the ability of company has benefited from asset and equity owned, ceteris paribus, the higher value of company. The results of study consistent with research by Sun \& Kim (2011) and Jacinta (2015). In contrast, NPM shows negative relationship between firm values. This result shows that a fall in NPM has had a negative impact on firm value. This means that the higher the margin is set by the company, this value the company would be down. A high gross margin basically will have an impact on the selling price products or services company. The fact that would be the grounds that investors do not want the selling price products company set high because in the long run will affect competitiveness company.

\section{Conclusion}

Based on the analysis of results and discussion, it can be concluded that Return on Investment and Return on Equity has positive and significant effect on company value, but Net Profit Margin negatively and significantly affects company value.

Limitations: (1). Examines the relationship between non-financial variables on company value, (2). Expand the object of the study to banking and finance industries or transportation sector.

\section{References}

Baye, M. R. (2006). Managerial Economics \& Business Strategy, 5th Ed, McGraw Hill, 16-19.

Brigham, E. F., Gapenski, L. C. \& Daves, P. R. (2006). Intermediate financial management.9th Edition. Florida: Dryden Press.

Callen, J. L. \& Segal, L. (2005).Empirical Tests of the Feltham-Ohlson (1995) Model. Review of Accounting Studies, 10, 409-429.

Huselid, M. A. \& Becker, B. E. (1997). The impact of high performance work systems, implementation effectiveness, and alignment with strategy on shareholder wealth. Paper presented at the 1997 Academy of Management Annual Conference, Boston, MA.

Jacinta, W. (2015). The Determinants of Manufacturer Firm Value in Indonesia Stock Exchange. International Journal of Information, Business and Management, 7(4).

Li-Ju, C. \& Shun-Yu, C. (2011). The influence of profitability on firm value with capital structure as the mediator and firm size and industry as moderators. Investment Management and Financial Innovations, 8(3).

Lestari, S. A. \& Armayah, M. (2016). Pengaruh Profitabilitas terhadap Nilai Perusahaan pada Perusahaan Manufaktur yang terdaftar Di Bursa Efek Indonesia Periode 2009 - 2014. Skripsi. Tidak Dipublikasikan.

Moeljadi. (2014). Factors affecting firm value: theoretical study on public manufacturing firms in Indonesia. South East Asia Journal of Contemporary Business, Economics and Law, 5(2).

Mursalim, H., Nur, A. \& Sanusi, A. (2015). Financial Decision, Innovation, Profitability and Company Value: Study on Manufacturing Company Listed in Indonesian Stock Exchange. Information Management and Business Review, 7(2), 72-78.

Ohlson, J. A. (1995). Earnings, Book Values and Dividends in Equity Valuation. Contemporary Accounting Research, 11 (spring).

Rajhans, R. K. \& Kaur, K. (2013). Financial Determinants of Firm's Value Evidence from Indian Firms. International Journal of Business Economics \& Management Research, 3(5).

Salvatore, D. (2005). Ekonomi Manajerialdalam Perekonomian Global. Salemba Empat: Jakarta. Schoubben, F., dan C. Van Hulle. 2004. The Determinant of Leverage: Difference between Quoted and Non Quoted Firms. Tijdschriftvoor Economie en Management, XLIX (4), 589-621. 
Shin-Ping, L. \& Hui-Ju, C. (2011). Corporate governance and firm value as determinants of CEO compensation in Taiwan: 2LS for panel data model. Management Research Review, 34(3), 256-265.

Sarngadharan, M. \& Rajitha, K. S. (2011). Financial Analysis of Management Decision. New Delhi: PHI Learning Private Limited.

Sun, K. A. \& Kim, D. Y. (2011). Customer satisfaction, profitability, and firm value in the hospitality and tourism industry: an application of American customer satisfaction index (ACSI). scholarworks.umass.edu/.../viewcontent.cgi?...hos.

Van Horne, J. C. \& Wachowicz, J. M. Jr. (2009). Fundamentals of Financial Management. Financial Times Press.

Vergos, K., Christopoulos, A. \& Kalogirou, V. (2016).Macroeconomic Factors as Determinants of Company Value in the Context of the Ohlson Residual Income Valuation Model; Greek Findings. 